Relations industrielles

Industrial Relations

\title{
Kumar, Pradeep, From Uniformity to Diversity : Industrial Relations in Canada and the United States
}

\section{Joseph B. Rose}

Volume 49, numéro 2, 1994

URI : https://id.erudit.org/iderudit/050944ar

DOI : https://doi.org/10.7202/050944ar

Aller au sommaire du numéro

Éditeur(s)

Département des relations industrielles de l'Université Laval

ISSN

0034-379X (imprimé)

1703-8138 (numérique)

Découvrir la revue

Citer ce compte rendu

Rose, J. B. (1994). Compte rendu de [Kumar, Pradeep, From Uniformity to Diversity: Industrial Relations in Canada and the United States]. Relations industrielles / Industrial Relations, 49(2), 404-406.

https://doi.org/10.7202/050944ar

Tous droits réservés (C) Département des relations industrielles de l'Université Laval, 1994
Ce document est protégé par la loi sur le droit d'auteur. L'utilisation des services d'Érudit (y compris la reproduction) est assujettie à sa politique d'utilisation que vous pouvez consulter en ligne.

https://apropos.erudit.org/fr/usagers/politique-dutilisation/ 
is urging us to confront is the separation of the field into two distinctive and largely unrelated approaches to research and professional practice.

In the beginning, in 1920, there was both a text book that linked IR and HR and an organization of practitioners that did the same. Kaufman is calling for a return to the roots, IR as an intellectual discipline linked intellectually and organizationally with HR but open to the other disciplines that have something to contribute to and learn from IR. Kaufman has provided a strong challenge based on an understanding of the evolution of the field in the U.S. Clearly this book is written about and for those involved in IR in the United States. The analysis and the prescriptions are, however, relevant well beyond the American borders. For Canadians, there are lessons to be learned even though on the surface, IR is still in a growth mode with the overall stability of union density (though patterns differ between the public and private sector).

The most important lesson is the strengthening of ties with HR and the broadening of the employment relations field. This has already been the approach followed in the most active centres of IR study and practice on the continent, in the universities and practitioner organizations in Quebec. Kaufman's book will undoubtedly be of wide interest not only in the U.S. but certainly in Canada as well. While the institutions and debates are most relevant to these two countries, the central themes that are explored will be important well beyond North America to all industrialized communities.

This book is a classic.

Noah M. MELTZ

University of Toronto

From Uniformity to Diversity: Industrial Relations in Canada and the United States, by Pradeep Kumar, Kingston, IRC Press, Queen's University, 1993, 195 p., ISBN 0-88886-369-1.

This book provides a comprehensive review of industrial relations developments in Canada and the United States. Specifically, it presents trends in union membership and density, compares the behaviour, goals and strategies of employers and unions, examines similarities and differences in labour policies between the two countries, and chimes in on the debate over whether there is convergence or divergence between the U.S. and Canadian industrial relations systems.

Broadly defined, the book considers the extent of divergence between industrial relations systems. As is evident from Kumar's review of previous research and available data, the "convergence-divergence" debate has produced a vast research literature. Kumar's analysis of the evidence leads him to conclude there is overwhelming support for concluding there is divergence in the U.S. and Canadian industrial relations systems. He makes a persuasive case. Kumar concludes divergence can be found "in all spheres of industrial relations activity - in patterns of union and management behaviour and strategies, collective bargaining approaches and outcomes, and in the scope and coverage of labour legislation and its administration' (at p. 143). Unions in Canada not only recorded larger membership gains and higher density rates, but they were more active 
in recruiting new members, more successful in achieving bargaining goals and exerted more political influence. The combination of social unionism, lower employer resistance to unionization and stronger labour laws have contributed to higher union effectiveness by Canadian unions.

In the course of his analysis, Kumar points out that most studies have focussed their attention on environmental factors to explain differences in union density and industrial relations systems. In assessing the role of enviromental factors, he finds that differences in national values and economic structures (e.g., greater public sector employment in Canada) are not strongly related to differences in the strength of unionism and collective bargaining in the two countries. Kumar does recognize the importance of labour policy as an environmental influence, but cautions that public policy in Canada, while more supportive of collective bargaining, should not be construed as prolabour. Moreover, he recognizes the importance of strategic-choice factors and notes environmental and strategic-choice explanations are not mutually exclusive. In other words, it is recognized there is dynamic interplay in the way unions and management choose to respond to a changing environment and in the approaches and strategies they develop to change the environment.

The strength of this book is the thoroughness with which Kumar reviews the empirical evidence. He not only makes aggregate comparisons of trends in union membership and density, but provides disaggregated comparisons by labour force characteristics (including broad comparisons for the public and private sectors), assesses the performance of major unions (both private and public sector unions), and utilizes a mini-case study of the auto industry to highlight differences in industrial relations practices in the two countries. His literature review is comprehensive and up-to-date. I have one small quibble withsome of the data he relies on. The figures on union membership and density are current, but the same cannot be said about union organizing and collective bargaining figures (which run to 1989 and 1988, respectively). While there may well be difficulty obtaining current certification figures, up-to-date figures are available on concession bargaining in both countries. Unlike most other studies, Kumar offers a broader comparison of labour policies. Most observers are familiar with the major differences in private sector collective bargaining legislation, including certification procedures, the role and powers of labour relations boards and the availability of first contract arbitration. Kumar extends the comparison to employment standards legislation and shows there is a superior "workers safety net" in Canada. Not only are employment standards often higher in Canada (e.g., minimum wage), but they offer broader coverage in areas such as vacation and holiday pay, maternity and paternity leave, and notice of termination and severance pay.

In the concluding section of the book, Kumar considers whether divergence will be enduring or temporary. Considering the foundation he laid in the rest of the book, this section is far too brief ( 5 pages). I would have preferred a lengthier discussion of the implications of his inquiry. For example, there could have been more discussion of the FTA with the U.S. and NAFTA, the difficulties facing public sector unions in Canada, the future of the labour-NDP relationship, and the prospects for labour law reform under President Clinton. Although some of these developments may have taken place subsequent to the publication of the book, others were either unfolding or 
predictable. Notwithstanding this minor shortcoming, this is a very good book and I highly recommend it.

Joseph B. Rose

McMaster University

Mutual Gains, A Guide to Union-Management Cooperation, by Edward CoHeNRosentHal, and Cynthia E. Burton, Ithaca, New York, ILR Press, 2nd ed. rev. 1993, 344 p., ISBN 0-87546-312-6.

Au moment où les expériences de coopération patronale-syndicale deviennent un sujet d'actualité, cette seconde édition mise à jour du livre « Mutual Gains » devrait connaître quelque succès. Ensemble, les auteurs ont travaillé à titre de consultants depuis plus de dix ans auprès d'organismes avec lesquels ils ont implanté divers projets de coopération patronale-syndicale. L'ouvrage ne se veut pas une analyse de la coopération mais bien un guide à l'intention de praticiens; il veut dire pourquoi et surtout comment coopérer pour en faire bénéficier les deux parties. D'ailleurs, les auteurs affirment dès l'entrée de jeu leur penchant tant pro-syndical que pro-patronal. L'expérience de travail d'un des auteurs dans certains organismes syndicaux ressort passablement du livre et en fait, à notre avis, un document aussi intéressant pour les syndicats que pour les gestionnaires et les consultants d'entreprises.

Au premier chapitre, les auteurs tentent de définir la coopération comme un des aspects des relations industrielles, parallèlement à son aspect conflictuel. Ils s'opposent ainsi à une certaine vision qui décrirait la coopération comme un changement radical de la culture managériale ouvrant la voie à une ère de paix sociale en Amérique du Nord. Bien que rapide, leur historique de la coopération patronale-syndicale aux États-Unis a au moins le mérite de montrer que ce phénomène a toujours pris une importance grandissante durant les périodes de crise économique et sociale, pour souvent disparaître par la suite.

Les auteurs définissent la coopération comme étant tout d'abord un objectif commun que syndicats et patronat peuvent identifier et réaliser conjointement. Mais, ajoutent-ils, la coopération ne veut pas dire la perte d'identité de chacune des parties, pas plus que l'absence de conflits. En cela, l'approche du livre se distancie de certaines tentatives patronales qui, de l'avis même des auteurs, voudraient se servir de la voie de la coopération pour mettre de côté les syndicats. Au contraire, et c'est l'idée maitresse du second chapitre, la relation de négociation telle qu'articulée dans la convention collective devrait constituer le fondement de tout projet de coopération. Et le ton du livre devient vite personnalisé lorsque les auteurs tentent de montrer, à l'intention aussi bien des syndicats (chapitre 2) que des directions d'entreprises (chapitre 3), les risques et les bénéfices de la coopération.

Ensuite, la seconde partie du livre tente de dresser un tableau des divers types de coopération patronale-syndicale, à différents niveaux. Ainsi, fidèles à leur approche voulant que la négociation collective soit le premier mécanisme de coopération syndicale-patronale en Amérique du Nord, les auteurs s'intéressent d'abord aux 